\title{
The anatomy of rose shoots
}

\author{
Marina Pashina* \\ Omsk State Pedagogical University, 644099 Omsk, Russia
}

\begin{abstract}
In may 2021, rose shoot samples of 3 rose species from 2 sections were collected: $R$. foetida from section Pimpinellfolia (DC.) Ser., $R$. majalis and $R$. rugosa from section Cinnamomeae (DC.) Ser. This article reviews anatomical structure of collected samples. The common attributes of rose stems anatomical structure are specified. The structure of vascular tissues is continuous. The differences in anatomy of the studied species are identified.
\end{abstract}

Woody plants are very important as a raw material in different types of industry. Many of them have been cultivated from long ago as decorative and fruit plants as well as a source of valuable medicinal substances. Thus, the anatomy of woody plants is being paid close attention not only by botany but also by forestry, forest genetics and selection, introduction, xylology [1, 2].

Controversial issues of taxonomy are solved using comparative anatomical method. Relative conservatism of anatomical attributes provides reasonable judgement on relationship of different taxons in different plant families [3, 4, 5, 6, 7, 8].

Fresh shoots were fixed and used to create permanent slides using polychrome coloring of plant tissues method conducted by Anatoly Ivanovich Mikhaltsov - the head of "Microcosm" laboratory [9].

Studied species showed similarity in stem anatomical structure. The epidermis has one layer with thin-walled membrane. The primary bark consists of collenchyma cells (exoderm), chlorophyllaceous parenchyma cells (mesoderm) and starch sheath (endoderm). Further there are areas of protophloem represented by lignified bast fibers collected in massive areas. Vascular tissues lie in solid rings. Perimedullary area separates wood from the medulla. Cells of two types are presented: most of them are polyhedral thin-walled transparent cells, others are small painted cells with various inclusions. 14].

$R$. foetida section Pimpinellifolia (DC.) Ser. 1825 [10, 11, 12], section Luteae [13,

The stem is covered with one-layer epidermis. Periderm is not large in volume and of typical structure. The primary bark consists of 4-5 lines of lamellar collenchyma, layers of parenchyma and simple endoderm. All bark tissues are painted brown. Stratified primary medullary rays are alternated with areas of protophloem fibres. The fibres are small and in few numbers. The solid ring of phloem is separated from the thick layer of wood by a thin layer of cambium with small cells placed in even rows.

*Corresponding author: $\underline{\text { mv_pashina@mail.ru }}$ 


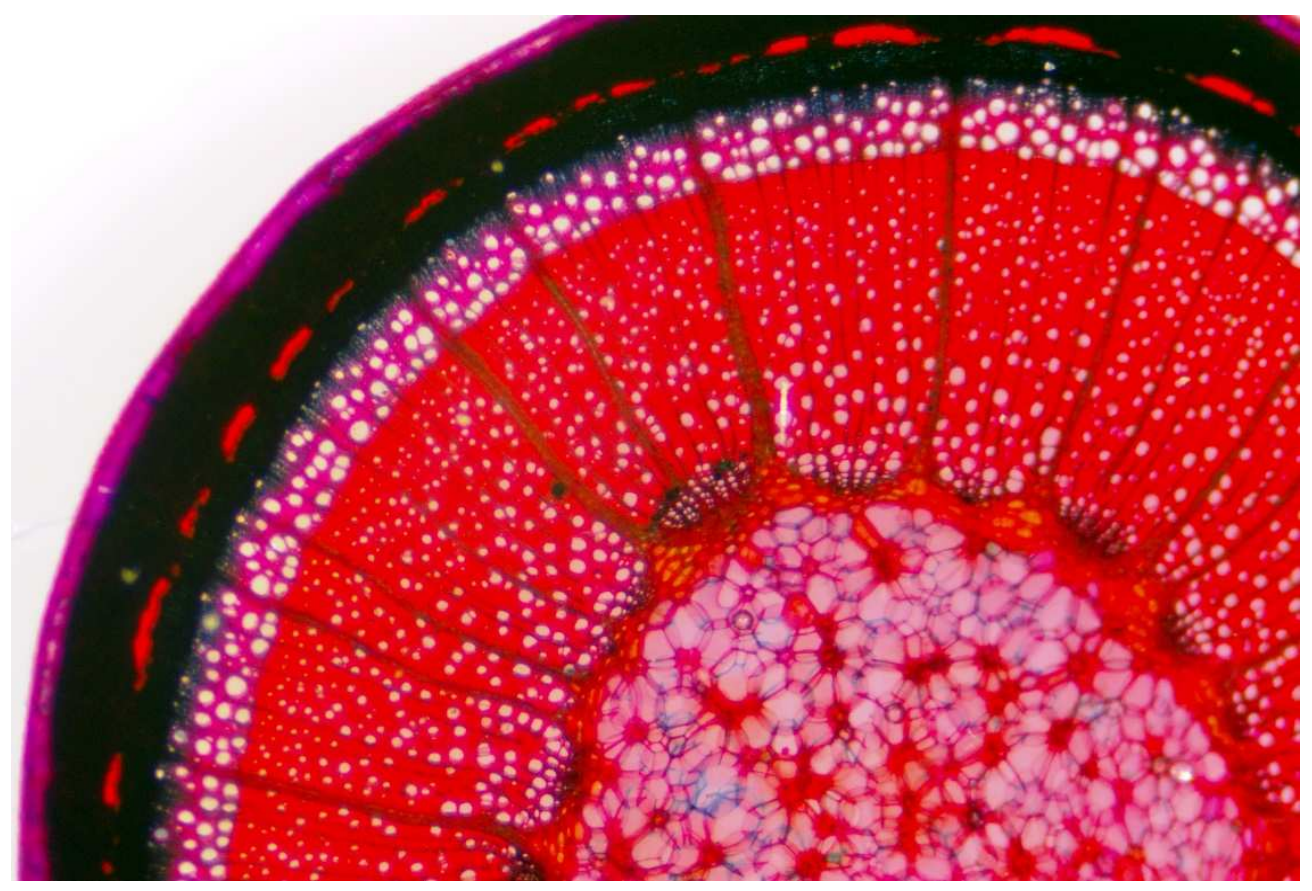

Fig. 1. The anatomical structure of the stem $R$. foetida

The wood has two well-discernible growth rings. Big amount of high-flow vessels lies in second-year springwood. The wood makes half of the volume pf the slide. The primary xylem consists of small-diameter vessels. Perimedullary area separates wood from the medulla. It contains small cells filled with starch. The medulla parenchyma contains a lot of 6-8-edged transparent cells. The medulla contains small 6-8-edged cells with various inclusions (Fig. 1).

R. majalis section Cinnamomeae (DC.) Ser. 1825 [10, 11, 12], section Rugosae [13, 14].

The slide contains a four-year-old branch. Along the periphery of the slide lies simple thin-walled epidermis. There is a complicated complex of periderm tissues lying deeper inside. The cell walls of phellem are suberized. These cells are deposited outwardly by phellogen, a living meristematic tissue, deeper, it deposits rounded living cells of phelloderm. The periderm is torn in 4-5 places and filled with small rounded parenchyma cells forming lenticel.

Primary bark areas are represented with three types of cells. The lamellar collenchyma of exoderm is sclerified. There is a small layer of mesoderm with cells of parenchymal type lying deeper. The endoderm is a simple starch sheath. The slide contains a small amount of primary medullary rays and some thick secondary rays starting from the phloem. Parenchyma cells separate the areas of sclerenchyma fibres.

Deeper there is a thick ring of bast with its cells forming a cambium. Cambium cell walls are thin. The cambium is placed in rows. It lays a large number of rows of wood inside the stem. 


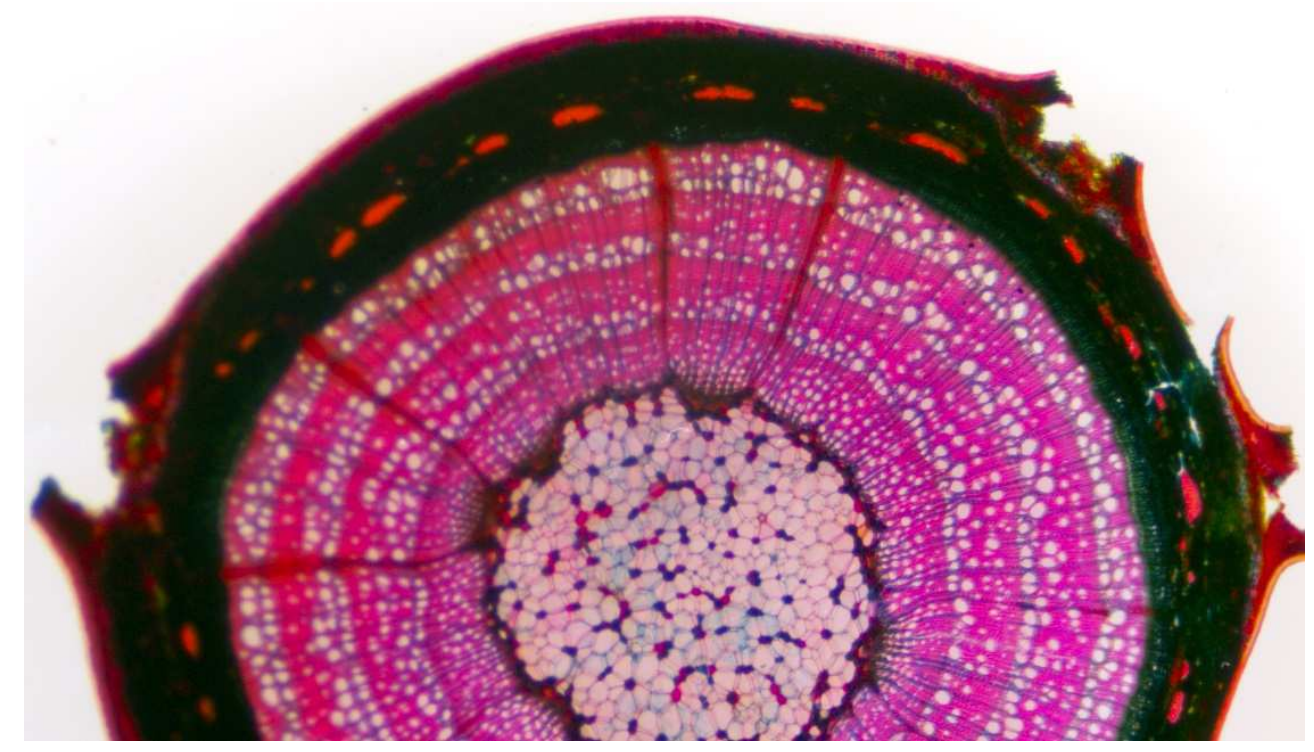

Fig. 2. The anatomical structure of the stem $R$. majalis

The wood of second or third year is of similar structure and contains about the same amount of spring and autumn wood. The fourth-year ring has only spring wood vessels formed. The first growth ring lies closer to the center. It is rather thick and contains a small number of thin-walled vessels and small parenchyma cells. Primal wood is separated from medulla with a thin ring of small cells of perimedullary zone that contains starch grains and painted dark-brown. There is a thick layer of medulla in the center with lesser number of cells with various inclusions and numerous 5-6-edged bigger cells (Fig.2).

\section{$R$. rugosa section Cinnamomeae (DC.) Ser. 1825 [10, 11, 12], section Rugosae [13, 14].}

Simple ephidermis with sparsely spaced thorn pads is replaced with periderm on the slide. The phellema is of 3-4 rows with cells containing intercellular spaces and suberized walls, painted dark-brown. Phellogen lies in 3 flat rows. The phelloderm is of 2-3 rows painted green. Lamellar collenchyma is of 4-5 rows, the primary bark collenchyma consists of 10 rows of densely packer cells and 1-2-row starch sheath of blue-green color.

Areas of bast fibres consist of big number of small lignified fibres painted pink. Thick phloem consists of soft and solid bast cells. Solid cambium ring is of 4 rows with cells placed in flat rows of dark-blue color. There is a beginning of the second growth ring of spring-autumn wood with big high-flow vessels in the secondary wood. The wood is of typical structure with lots of primary stratified cells and secondary simple medulla rays. Perimedullary zone is of 3-4 rows with small cells without intercellular spaces, with cell walls evenly thickened, painted brown.

The medulla is very thick-developed and makes more than half of the slide volume. It consists of numerous big 5-8-edged thin-walled cells. There is a lot of small cells painted in different shades of brown (Fig.3). 


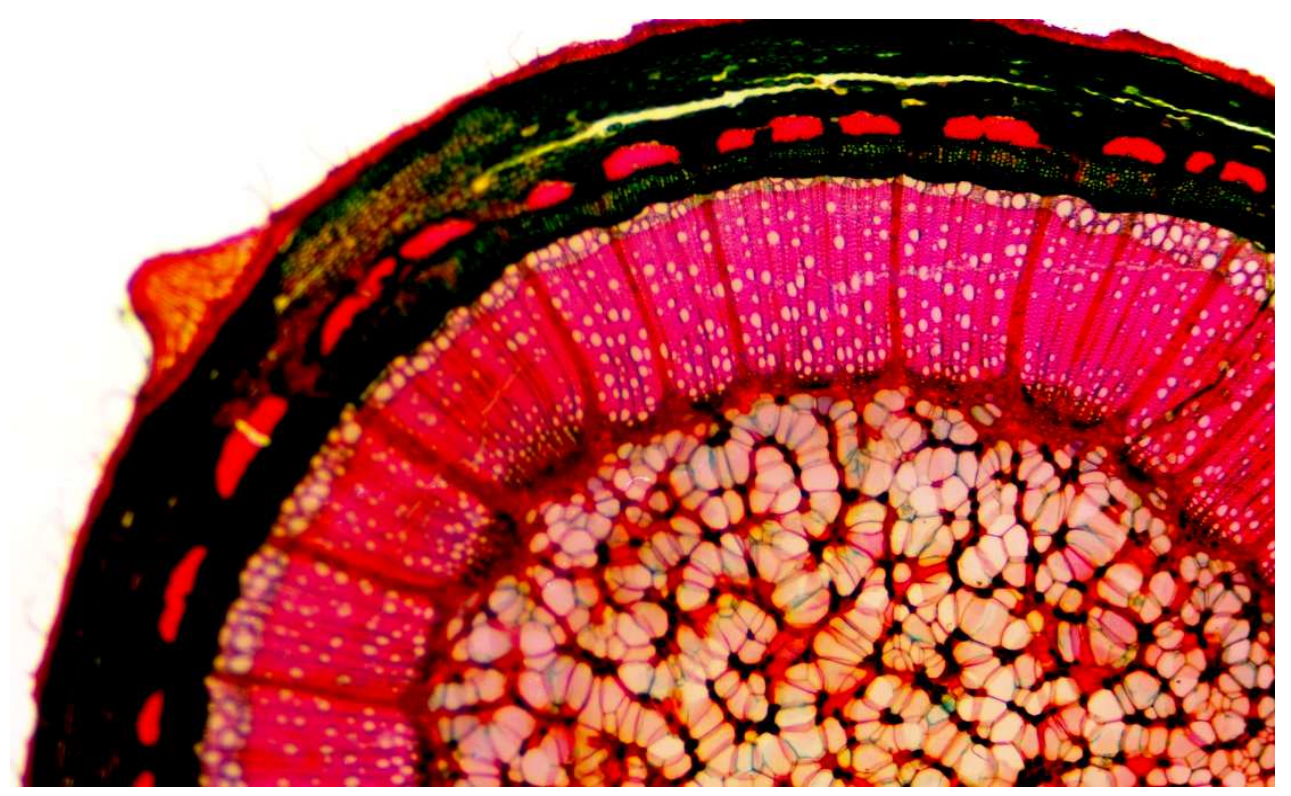

Fig. 3. The anatomical structure of the stem $R$. rugosa

The differences in the structure of 3 studied species are revealed. Perennial branch of $R$. majalis. $R$. foetida and $R$. rugosa is represented with annual shoots.

$R$. majalis has multilayer periderm torn in several places with formed lenticel under its epidermis. Bask fibre areas are of small number. The wood consists of 4 growth rings.

$R$. rugosa has thorn pads tightly filled with small parenchyma cells above its epidermis. There is no periderm. There are big areas of bask fibres. There is a thick-developed medulla parenchyma in the center that takes more than half of the stem.

$R$. foetida has a small layer of periderm, the wood and medulla are very thickdeveloped.

\section{Reference}

1. L. I. Lotova, Morphology and anatomy of higher plants (Moscow, Editorial URSS, 2001)

2. L. I. Lotova, A. K. Timonin, Anatomy of the bark of Rosaceae: diversity, evolution, taxonomic significance (Moscow, KMK, 2005)

3. A. A. Yatsenko-Khmelevsky, Essay on the history of wood anatomy (Yerevan, Publishing House of the Academy of Sciences of the Armenian SSR, 1946)

4. A. A. Yatsenko-Khmelevsky, Fundamentals and methods of anatomical study of wood (Moscow, Publishing House of the Academy of Sciences of the USSR, 1954)

5. B. M. Kozo-Polyansky, Problems of botany 1 (1950)

6. A. L. Takhtadzhyan, System and phylogeny of flowering plants (M.-L., Nauka, 1966)

7. E. A. Sokolova, Morphological and anatomical features of the structure of the vegetative organ of the shoot of representatives of the genus Armeniaca (Leningrad, 1986)

8. V. N. Sorokopudov, N. N. Netrebenko, M. V. Evtukhova, D. I. Pisarev, Bulletin of the Krasnoyarsk State. agrarian university 11 (2009) 
9. A.I. Mikhaltsov, Natural Resources, Biodiversity and Prospects for Natural Science Education (Omsk, Omskblankizdat, 2012)

10. V. Wissemann, Classification/Conventional taxonomy (wild roses) (London, Academic Press, 2003)

11. V. Wissemann, C. Ritz, Botanical J. 147 (2005)

12. V. Wissemann, Plant evolution by means of hybridization. Systematics and Biodiversity 5 (2007)

13. V. G. Khrzhanovsky, Roses (Moscow, Sov. Science, 1958)

14. I. O. Buzunova, Flora of Eastern Europe., Vol. 10. (SPb., 2001) 